\title{
Analisis Strategi Pemasaran Ternak Berbasis E-Commerce di PT X
}

\author{
Analysis of E-Commerce Based Livestock Marketing Strategies at PT X \\ L. Aprilia ${ }^{1}$, L. Cyrilla ${ }^{1}$, \& Burhanuddin ${ }^{2}$ \\ ${ }^{1}$ Departemen Ilmu Produksi dan Teknologi Peternakan, Fakultas Peternakan, IPB \\ ${ }^{2}$ Departemen Agribisnis, Fakultas Ekonomi dan Manajemen, IPB \\ Email koresponden author: luciwanto@gmail.com
}

\begin{abstract}
PT $\mathrm{X}$ is one of the online livestock marketplace companies that connects partners (housing investors, business partners, members, and farmers) with consumers. Products that were marketed by PT X include sheep (gembel, garut, merino) and cow (ongol, hisar, simmental). PT X in marketing its products used online marketing system based on e-commerce. This research was a case study research with qualitative approach that aimed to analyze the marketing strategy of livestock in PT X. This research used direct interview method that was involving all respondents as many as 3 managers of PT $X$ and 1 expert respondents. The data were analyzed using AHP (Analytical Hierarchy Process) method and presented descriptively. There are 3 interrelated elements in analyzing the marketing strategy of PT $X$ 's online livestock, including factors (delivery and product availability systems) of actors (Founder, Coordinator of Mobile Centers, and Support Service) and alternatives (maintaining product quality, expanding cooperative relationships, and improve service system).This study concluded that product availability is a priority factor with the Mobile Sentra Coordinator having the most important role as an actor in the preparation of PT X's marketing strategy. Maintaining product quality becamethe main strategy that coulds be applied by PT $\mathrm{X}$ in increasing its marketing.
\end{abstract}

Keywords: AHP, e-commerce, livestock, marketplace

\section{PENDAHULUAN}

Ternak ruminansia memiliki potensi besar untuk dikembangkan sebagai pemanfaatan daging, wol, kulit, dan susu. Wiradarya (2004) menyatakan usaha ternak bagi masyarakat masih cenderung bersifat usaha sampingan atau belum sepenuhnya berorientasi komersial, sehingga sistem usaha yang dilakukan masih konvensional dengan skala pemilikan usaha yang relatif kecil. Apabila usaha peternakan ingin dijadikan sebagai sumber pendapatan utama bagi masyarakat, perlu upaya pengembangan usaha agar menjadi kegiatan usaha pokok berbasis komersil. Usaha ternak komersil dapat dilakukan dengan menghimpun petani-petani kecil menjadi suatu organisasi seperti Sentra Peternakan Rakyat (SPR) dengan pemasaran berbasis e-commerce.

Seiring dengan perkembangan era digital, akses internet semakin mudah dijangkau oleh masyarakat. Data yang dirilis oleh Asosiasi Penyelenggara Jasa Internet Indonesia, pengguna internet terus tumbuh sejak abad ke18. Pada tahun 1998 pengguna internet di Indonesia hanya 0,5 juta orang dan naik menjadi 132,7 juta pengguna di tahun 2016. Pengguna internet yang terus tumbuh semakin meningkatkan frekuensi akses internet. Akses internet yang dilakukan masyarakat memiliki tujuan beragam seperti berkirim pesan, memasarkan produk, dan berbelanja online. Chen et al. (2010) menyatakan berbelanja online merupakan suatu dampak dari penggunaan internet yang memungkinkan konsumen untuk menyebarkan positive word of mouth yang akan memberikan efek promosi ke konsumen lain. Efek promosi yang diberikan dari kegiatan berbelanja online tersebut memberikan peluang dalam pemasaran produk. Efek promosi berbelanja online membantu dalam pemasaran produk lebih luas dengan sistem e-commerce.

E-commerce adalah strategi komersial baru yang mengarah pada peningkatan kualitas produk dan layanan serta perbaikan ditingkat layanan penyediaan sementara link persyaratan organisasi, pemasok, juga konsumen ke arah mengurangi biaya (Shaw et al. 2012). Sistem pemasaran berbasis e-commerce membantu peternak dalam memasarkan ternaknya secara luas. Pemasaran berbasis e-commerce ini semakin dipermudah dengan adanya aplikasi khusus pemasaran ternak yang dibuat oleh PT X. Marketplace adalah ruang online pembeli dan penjual bertemu untuk melakukan transaksi yang melibatkan barang atau jasa. PT X merupakan suatu perusahaan marketplace yang membantu dalam pemasaran ternak secara online melalui aplikasi online. 
Aplikasi tenak online PT X sebagai marketplace dilengkapi informasi tentang jenis, bangsa, bobot, dan keterangan lainnya mengenai ternak yang dipasarkan, sehingga penjualan tetap aman dilakukan meskipun melalui dunia maya. Oleh karena itu, dengan berbagai kemudahan yang ditawarkan oleh aplikasi online dalam melakukan pemasaran ternak maka perlu dikaji lebih lanjut mengenai sistem pemasaran online ternak mengggunakan aplikasi online. Penelitian ini dilakukan untuk menganalisis strategi pemasaran ternak online yang tepat di PT X sebagai marketplace.

\section{MATERI DAN METODE}

\section{Waktu dan Tempat Penelitian}

Penelitian dilakukan di daerah Jakarta Pusat. Pengumpulan data pada bulan April sampai dengan Juli 2018.

\section{Desain Penelitian}

Penelitian ini menggunakan desain studi kasus. Rahardjo dan Gudnanto (2011) menyatakan bahwa studi kasus merupakan metode yang diterapkan untuk memahami individu lebih mendalam dengan dipraktekkan secara integratif dan komprehensif. Hal ini dilakukan agar peneliti dapat mengumpulkan dan mendapatkan pemahaman mendalam mengenai individu yang diteliti.Penelitian didesain untuk menganalisis strategi pemasaran PT X dalam meningkatkan produktivitas perusahaan.

\section{Alat}

Alat yang digunakan pada penelitian ini yaitu kuisioner yang memuat pertanyaan bagi responden, alat tulis, laptop, dan kamera untuk dokumentasi.

\section{Responden}

Responden dalam penelitian ini meliputi Founder, CoFounder, Koordinator Mobile Sentra, Support Service. PT X dan responden ahli. Responden ahli merupakan seorang akademisi dibidang komunikasi bisnis. Pemilihan responden didasarkan pada tujuan penelitian yaitu pihak- pihak yang berhubungan dengan strategi pemasaran ternak online. Responden yang dipilih memberikan informasi yang dibutuhkan untuk kepentingan strategi pemasaran ternak online PT X. Co-Founder menjadi responden yang memberikan informasi yang dibutuhkan mengenai PT X. Founder, Koordinator Mobile Sentra, dan Support Service PT $\mathrm{X}$ berperan dalam mengisi kuisioner perbandingan komparasi berpasangan pada bagian faktor dan alternatif. Responden ahli berperan dalam mengisi kuisioner perbandingan komparasi berpasangan pada bagian aktor.

\section{Data}

Penelitian ini menggunakan 2 jenis data, yaitu data primer dan data sekunder. Data primer diperoleh melalui pengisian kuesioner dan wawancara yang didapat dari narasumber atau informan. Data sekunder diperoleh dari berbagai literatur yang relevan dengan topik yang dibahas.

Tahap awal $\begin{gathered}\text { Prosedur } \\ \text { penelitian dilakukan dengan }\end{gathered}$ mengumpulkan data sekunder mengenai PT X dan sistem pemasaran ternak secara online. Data tersebut kemudian digunakan dalam pembuatan kerangka berpikir. Kerangka berpikir yang disusun terdiri atas tujuan, faktor, aktor, dan alternatif. Tujuan yang dicapai dalam kerangka berpikir ini disesuaikan dengan tujuan perusahaan terkait. Penentuan faktor tersebut dipengaruhi oleh indikator yang dapat mendorong tercapainya tujuan. Aktor ditentukan berdasarkan pengaruhnya dalam penentuan strategi pemasaran ternak online. Alternatif yang dibuat menjadi solusi untuk mencapai tujuan perusahaan terkait. Kerangka berpikir dan kuisioner yang telah disusun kemudian disesuaikan dengan keadaan perusahaan. Gambar 1 menyajikan kerangka pikir dari strategi pemasaran online ternak.

Tahap selanjutnya dalam metode AHP (Analytical Hierarchy Process) ialah pembuatan matriks perbandingan komparasi berpasangan berdasarkan kerangka berpikir yang ada. Matriks perbandingan komparasi berpasangan digunakan sebagai kuisioner AHP. Penilaian pada kuisioner AHP dilakukan oleh responden yang telah ditentukan.

STRATEGI PEMASARAN ONLINE TERNAK

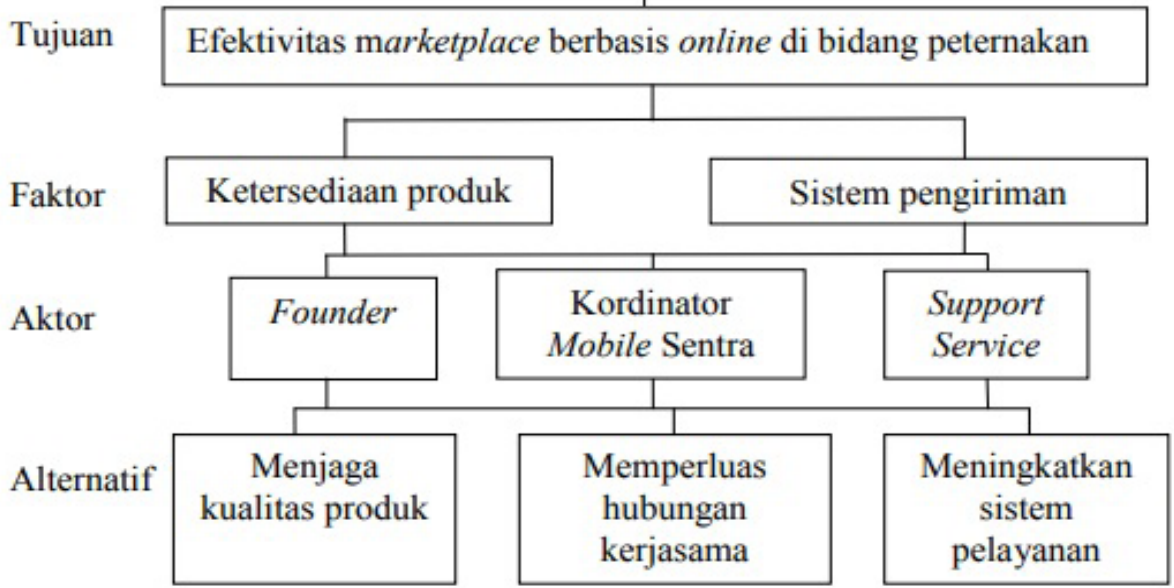

Gambar 1. Kerangka pemikiran strategi pemasaran online ternak 
Tabel 1. Nilai skala banding berpasangan

\begin{tabular}{|c|c|c|}
\hline $\begin{array}{l}\text { Tingkat } \\
\text { Kepentingan }\end{array}$ & Definisi & Keterangan \\
\hline 1 & Kedua unsur sama pentingnya & Kedua unsur menyumbang sama besar pada sifat itu \\
\hline 3 & Unsur yang satu sedikit lebih penting daripada yang lainnya & $\begin{array}{l}\text { Pengalaman dan pertimbangan sedikit menyokong satu } \\
\text { unsur atas yang lainnya }\end{array}$ \\
\hline 5 & Unsur yang satu sangat penting daripada yang lainnya & $\begin{array}{l}\text { Pengalaman dan pertimbangan dengan kuat menyokong } \\
\text { satu unsur atas yang lainnya }\end{array}$ \\
\hline 7 & Satu unsur jelas lebih penting dibanding yang lain & $\begin{array}{l}\text { Satu unsur dengan kuat disokong dan dominannya telah } \\
\text { terlihat dalam praktek }\end{array}$ \\
\hline 9 & Satu unsur mutlak lebih penting dibanding yang lain & $\begin{array}{l}\text { Bukti yang menyokong unsur yang satu atas yang lainnya } \\
\text { memiliki tingkat penegasan yang kuat }\end{array}$ \\
\hline $2,4,6,8$ & Nilai diantara 2 penilaian yang berdekatan & Kompromi diperlukan di antara 2 pertimbangan \\
\hline
\end{tabular}

Sumber: Saaty (2001)

Kriteria penilaian kuisioner berdasarkan pada Tabel 1. Hasil penilaian yang didapatkan diolah menggunakan Software Expert Choice 11. Penilaian bergantung pada pengalaman, pengetahuan, dan penafsiran peneliti terhadap masalah dan kerangka pemikiran yang telah disusun agar dapat dimengerti oleh responden.

\section{Analisis Data}

Analisis data menggunakan metode analisis deskriptif. Pengolahan data penelitian menggunakan Software Expert Choice 11. Data yang didapatkan pada penelitian berasal dari bukan responden ahli dan responden ahli diinputkan kedalam Software Expert Choice 11. Data yang diinput, dievaluasi inkonsistensinya pada setiap unsur kerangka berpikir dengan batas inkonsistensi $\leq 10 \%$. Data yang memenuhi batas inkonsistensi $\leq 10 \%$ diurutkan setiap unsurnya berdasarkan skala prioritasnya. Alternatif yang memenuhi kriteria dengan nilai prioritas tertinggi merupakan alternatif yang digunakan.

\section{HASIL DAN PEMBAHASAN}

\section{Gambaran Umum Perusahaan}

PT X merupakan perusahaan marketplace beternak online yang didirikan pada tahun 2016 dengan pengelola berjumlah 6 orang. Pengelola PT X meliputi 1 orang Founder, 2 orang Co-Founder, 2 orang Koordinator Mobile Sentra, dan 1 orang Support Service. Perusahaan ini menyediakan layanan beternak online dalam bentuk aplikasi mobile, sehingga beternak dapat dilakukan secara praktis tanpa harus memiliki lahan, keterampilan, dan waktu. PT X dalam mengelola sistem beternak online menawarkan sistem kemitraan. Kemitraan yang ditawarkan meliputi investor kandang, mitra bisnis, member,dan peternak rakyat. Berikut definisi mitra-mitra yang ditawarkan oleh PT X.

\section{Investor Kandang}

Investor kandang merupakan mitra yang berinvestasi dalam bentuk kandang, lahan atau, pendanaan yang digunakan sebagai tempat pemeliharaan hewan ternak. Investor kandang tersebut wajib memenuhi standar persyaratan lokasi lahan kandang PT X. Standar persyaratan lokasi lahan kandang PT X meliputi lahan memanjang timur ke barat, tersedia jalan yang dapat dilalui truk ukuran muatan minimal 5 ton, sumber air bersih layak minum yang mencukupi sepanjang tahun, sumber listrik PLN 3 phase, dan berlokasi ditempat yang aman. Investor yang telah memenuhi persyaratan dapat mendaftarkan diri dengan cara mengisi formulir permohonan menjadi investor kandang pada website resmi PT X.

Investor kandang yang telah menjadi mitra PT X dapat memperoleh keuntungan. Keuntungan yang ditawarkan PT X meliputi uang sewa dari jumlah bibit ternak bakalan domba maupun sapi yang diternakkan dalam kandangnya dan hasil penjualan dari produksi pupuk kandang, insentif kandang dari penjualan setiap $\mathrm{kg}$ pertumbuhan berat ternak yang dilakukan secara proporsional dan transparan, dan transfer ilmu pengetahuan, teknologi, serta inovasi-inovasi dalam hal pemeliharaan domba dan sapi.

\section{Mitra Bisnis}

Mitra bisnis merupakan pihak yang menjalin kerjasama dalam jangka waktu tertentu dengan PT X. Mitra bisnis tersebut merupakan bagian dari pembeliternak yang dijual oleh PT X. Mitra bisnisPT X meliputi pihak RPH dan restaurant. Ternak yang dijual kepada mitra bisnis merupakan ternak milik member yang tidak dijual secara langsung kepada konsumen dengan bobot badan ternak yang tidak mencapai target setelah pemeliharaan selama 3 bulan.

\section{Member}

Member merupakan mitra yang berinvestasi dalam bentuk hewan ternak. Ternak yang diinvestasikan oleh member meliputi domba dan sapi. Ternak didapatkan member melalui pembelian yang dilakukan diaplikasi milik PT X. Ternak milik member nantinya akan dipelihara oleh PT X dan dapat dijual kembali setelah mencapai bobot badan. Pemeliharaan ternak member dilakukan selama 3 bulan. Ternak yang telah selesai dipelihara lalu dijual oleh PT X melalui aplikasi dengan keuntungan yang didapatkan diberikan pada member.

\section{Peternak Rakyat}

Peternak rakyat merupakan mitra PT X yang bertanggung jawab dalam mengelola ternak milik member. Kemitraan sebagai peternak memiliki 2 bagian yang berbeda, yakni peternak dalam arti seseorang yang menginvestasikan 
ternaknya untuk dipasarkan secara online dan peternak yang menginvestasikan keterampilannya untuk memelihara ternak. Peternak yang menginvestasikan ternaknya tergabung dalam suatu kelompok seperti SPR (Sentra Peternakan Rakyat) yang tersebar di daerah Semarang, Yogyakarta, dan NTB.

Peternak rakyat yang memiliki keterampilan memelihara ternak dapat berinvestasi dengan mendaftarkan diri melalui website PT X dan memenuhi persyaratan yang terlampir. Persyaratan untuk menjadi peternak rakyat yaitu usia produktif, sehat jasmani dan rohani serta memiliki keinginan belajar dan bekerja keras. Peternak rakyat yang terdaftar berkewajiban untuk mengikuti proses pelatihan, bersedia ditempatkan di lokasi kandang, serta bekerja penuh dedikasi dan tanggung jawab. Peternak rakyat yang telah menjadi mitra akan mendapatkan hak berupa gaji bulanan, bonus pencapaian target, dan pelatihan serta sertifikat.

\section{Gambaran Umum Aplikasi}

\section{Beternak Online}

PT X merupakan marketplace dalam pemasaran ternak online melalui aplikasi mobile phone yang memudahkan pengguna dalam beternak. Penggunaan aplikasi beternak online dilakukan melalui 3 langkah yaitu membeli ternak lalu perusahaan (PT X) akan memelihara ternak tersebut selama periode 3 bulan, dan ternak tersebut dapat dijual kembali oleh pengguna aplikasi (member). Pembelian ternak dapat dilakukan dengan memilih ternak yang disediakan oleh aplikasi beternak online. Member kemudian membayar sejumlah biaya yang meliputi harga ternak dan biaya pemeliharaan selama 3 bulan oleh peternak rakyat. Pemilik ternak (member) dapat memantau pertambahan bobot badan ternak melalui aplikasi beternak online pada tanggal 10 dan 25 setiap bulannya.

PT X sebagai pelopor sistem beternak online terus mengembangkan fasilitasnya bagi konsumen. Saat ini terdapat aplikasi serupa yang menawarkan sistem beternak online seperti PT X seperti situs Jualternak.com. Aplikasi beternak online PT X memberikan fasilitas asuransi untuk ternak yang dijual sehingga pembeli akan merasa lebih aman. Sistem pembayaran yang ditawarkan PT X lebih aman karena bekerjasama dengan perusahaan layanan provider dan perbankan. PT X juga tidak hanya menawarkan penjualan ternak tetapi juga investasi ternak.

\section{Analisis Bauran Pemasaran}

Bauran pemasaran setiap variabelnya saling berhubungan dan tergantung satu sama lain. Assauri (2015) menyatakan bauran pemasaran merupakan kombinasi variabel atau kegiatan yang merupakan inti dari sistem pemasaran, variabel yang dapat dikendalikan oleh perusahaan untuk mempengaruhi reaksi para pembeli atau konsumen. Zeithaml dan Bitner (2010) menyatakan bahwa konsep bauran pemasaran tradisional terdiri dari 4P, yaitu: product, price, place, dan promotion. Sementara itu, untuk pemasaran jasa perlu bauran pemasaran yang diperluas dengan penambahan unsur non-tradisional yaitu people, physical environment, dan process, maka menjadi 7P. Berdasarkan hasil penelitian diketahui bahwa variabel product, price, place, promotion, people, physical environment, dan processberpengaruh terhadap strategi pemasaran ternak online pada PT X.

\section{Product (Produk)}

PT X sebagai perusahaan penyedia marketplace beternak online memiliki orientasi pasar yang lebih mengarah ke konsep produk ternak yaitu menganggap bahwa konsumen lebih memilih tawaran pasar yang menyediakan kemudahan dalam berbelanja hewan ternak dan inovatif. Produk adalah pemahaman subyektif dari produsen atas sesuatu yang bisa ditawarkan, sebagai usaha untuk mencapai tujuan organisasi melalui pemenuhan kebutuhan dan keinginan konsumen, sesuai dengan kompetensi dan kapasitas organisasi serta daya beli pasar (Tjiptono 2002). Produk PT X meliputi ternak domba (gembel, garut, merino) dan sapi (ongol, hisar, simmental).

PT X dalam memasarkan ternaknya mencantumkan informasi pendukung yang tertera pada aplikasi. Informasi tersebut meliputi jenis ternak, harga, bobot, umur, tingkat pertumbuhan,lokasi pemeliharaan, serta foto ternak yang dipasarkan. Ternak yang dipelihara PT X selama 3 bulan diberi informasi penambahan bobot ternak sebanyak 2 kali dalam sebulan. Ternak domba mengalami penambahan bobot sebesar 0,11-0,14 kg per hari dan ternak sapi mengalami penambahan bobot $0,8-1,8 \mathrm{~kg}$ per hari. Ternak yang dipelihara tersebut telah terlebih dahulu didaftarkan dalam asuransi ternak untuk menghindari kerugian pada konsumen jika ternak mengalami kematian. Premi asuransi tersebut dibayarkan oleh konsumen melalui PT X yang telah tergabung dalam harga beli ternak.

\section{Price (Harga)}

Harga adalah salah satu unsur bauran pemasaran yang dapat dikendalikan oleh perusahaan. Harga merupakan penentuan penjualan produk sekaligus mempengaruhi pendapatan perusahaan. PT X sebagai suatu perusahaan beternak online dapat menetapkan harga produk yang dipasarakan. Produk yang ditawarkan oleh PT X merupakan hewan ternak.

Harga ternak ditetapkan berdasarkan bobot ternak yang ditawarkan dan biaya pemeliharaan. Selain itu, harga yang ditetapkan sudah termasuk biaya asuransi ternak dalam mengantisipasi jika ternak mengalami kematian. Harga ternak yang dipasarkan PT X berkisar Rp 19000000 untuk sapi dan Rp 2000000 untuk domba setiap ekornya. Harga jenis sapi dan domba yang dijual disesuaikan dengan harga pasar. Harga ternak di PT X umumnya mengalami peningkatan saat hari raya Idul Fitri dan Idul Adha.

\section{Place (Lokasi)}

Lokasi adalah tempat kegiatan perusahaan untuk membuat produk yang dihasilkan/dijual terjangkau dan tersedia bagi pasar sasaran. PT X sebagai perusahaan marketplace beternak online memiliki tempat produksi dan kantor pusat yang berbeda. Tempat produksi digunakan PT $\mathrm{X}$ dalam pemeliharaan dan pengembangan produk hewan ternak yang dipasarkan. Pemeliharaan ternak tersebut meliputi pemberian pakan, pengecekan kesehatan ternak, dan memelihara kebersihan kandang. 
Lokasi pemeliharaan tersebut tersebar di 3 wilayah Indonesia yaitu Semarang, Yogyakarta, dan NTB. NTB memiliki jumlah SPR terbanyak dibandingkan wilayah lainnya sedangkan wilayah Semarang dan Yogyakarta memiliki transaksi penjualan lebih tinggi dibandingkan NTB. Tempat produksi ini merupakan hasil kerjasama PT $\mathrm{X}$, SPR, dan member dalam memelihara hewan ternak yang dipasarkan. Kantor pusat PT X sendiri terletak di daerah Jakarta Pusat.

\section{Promotion (Promosi)}

PT $\mathrm{X}$ beriorientasi dalam pengembangan pasar dan pelanggan baru. PT X dalam mencapai orientasi tersebut melakukan promosi produk menggunakan media sosial. Promosi adalah komunikasi dari para penjual yang menginformasikan, membujuk, dan mengingatkan para calon pembeli suatu produk dalam rangka mempengaruhi pendapat mereka atau memperoleh suatu respon (Lambet al. 2001).

Promosi melalui media sosial menampilkan PT X sebagai suatu perusahan pelopor dalam sistem beternak online. Promosi dilakukan dengan menampilkan kemudahan beternak dengan menggunakan aplikasi beternak online. Media sosial yang digunakan PT X dalam promosi meliputi instagram dan situs website.

\section{People (Orang)}

Orang adalah semua pelaku yang memiliki peran penting dalam penyajian jasa sehingga dapat mempengaruhi persepsi pembeli. PT $\mathrm{X}$ dalam penentuan strategi pemasarannya dipengaruhi oleh beberapa aktor yang berperan penting dalam menyampaikan jasa yang ditawarkan perusahaan. Aktor yang memiliki peran penting tersebut meliputi Founder, Kordinator Mobile Sentra, dan Support Service. Sikap dan tindakan aktor tersebut memiliki pengaruh terhadap keberhasilan penyampaian jasa yang diberikan perusahaan. PT X dalam menyampaikan jasanya menyediakan seorang Support Service yang menjadi jembatan antara konsumen dan perusahaan dalam berkomunikasi.

\section{Physical Environment (Bukti Fisik)}

Bukti fisik adalah tempat jasa diberikan dan tempat pelanggan dan perusahaan melakukan interaksi serta komponen lain yang membantu meningkatkan pelayanan jasa yang diberikan. Cantet al. (2006) menyatakan bahwa bukti fisik terdiri atas fasilitas fisik dan unsur komunikasi yang nyata. PT X sebagai suatu perusahaan marketplace online melakukan interaksi antara pembeli dan penjual secara online sehingga bukti fisik transaksi diperoleh melalui tanda bukti pembelian ternak, pembayaran, kesehatan ternak, dan penambahan bobot badan ternak yang dipelihara setiap bulannya.

Tanda bukti pembelian akan dikirimkan oleh PT X ke alamat $e$-mail pembeli. Bukti pembelian yang ada dalam e-mail tersebut dapat dicetak oleh pembeli menjadi bukti fisik. Informasi mengenai kesehatan, penambahan bobot badan, dan informasi pendukung lainnya dicantumkan di dalam aplikasi dan dikirimkan ke alamat e-mail mitra yang bersangkutan. Bukti pembayaran ternak yang dibeli dapat diperoleh melalui perbankan yang digunakan dalam proses pembayaran. Bukti fisik pembayaran dapat berbeda bentuknya yang disesuaikan dengan media pembayarannya seperti ATM, e-banking, atau pengiriman langsung melalui teller bank.

\section{Process (Proses)}

Proses (process) adalah kegiatan yang menunjukkan bagaimana pelayanan diberikan kepada konsumen selama melakukan pembelian barang. Proses pembelian barang pada produk PT X dilakukan secara online melalui aplikasi yang disediakan. Pelayanan yang diberikan perusahaan selama pembelianpun dilakukan secara online melalui aplikasi PT X. Pembeli yang ingin melakukan pembelian terlebih dahulu melakukan login ke dalam aplikasi dengan memasukkan username dan password yang didapatkan setelah registrasi. Pembeli yang telah login dapat memilih ternak yang akan dibeli. Selama proses pembelian para pembeli memilih hewan ternak secara mandiri pada aplikasi. Aplikasi beternak online mencantumkan informasi mengenai ternak yang dijual agar para pembeli dapat mengetahui keadaan ternak.

Ketujuh bauran pemasaran tersebut kemudian dikombinasikan untuk merumuskan alternatif yang dapat digunakan dalam strategi pemasaran ternak berbasis e-commerce di PT X. Hasil kombinasi ketujuh bauran pemasarn didapatkan 3 alternatif yang digunakan yaitu menjaga kualitas produk, memperluas hubungan kerjasama, dan meningkatkan sistem pelayanan. Alternatif menjaga kualitas produk merupakan hasil kombinasi dari bauran product (produk), price (harga), place (lokasi), dan process (proses). Alternatif memperluas hubungan kerjasama merupakan hasil kombinasi dari bauran place (lokasi), promotion (promosi), dan process (proses). Alternatif meningkatkan sistem pelayanan merupakan hasil kombinasi dari bauran people (orang ), physical environment (bukti fisik), dan process (proses).

\section{Analisis Unsur Strategi Pemasaran}

\section{Ternak Online PT X}

Terdapat 3 unsur yang saling terkait dalam menganalisis strategi pemasaran ternak online PT X, antara lain unsur faktor, aktor, dan alternatif. Strategi pemasaran adalah kinerja wirausaha dengan hasil penjualan dan penelitian pasar sebelumnya di dalam mengembangkan keberhasilan strategi pemasarann (Echdar 2013). Ketiga unsur tersebut selanjutnya disusun ke dalam hirarki lengkap yang terdiri atas :

\section{Faktor}

Ketersediaan produk. Jumlah produk yang dipasarkan dalam pemasaran online harus ditentukansecara akurat agar sesuai dengan permintaan pasar. Jumlah ketersediaan produk yang tepat dapat menghindarkanperusahaan dari permasalahan stockout (kehabisan persediaan) dan overstock (kelebihan persediaan). PT X sebagai perusahan yang menawarkan ternak dengan sistem pemasaran online harus senantiasa memastikan jumlah ternak yang tersedia sesuai dengan 
permintaan pasar. PT X bergantung kepada SPR dalam menyediakan produk yang dipasarkan sedangkan mitra SPR terbatas jumlahnya sehingga PT X pernah mengalami stockout. Stockout tersebut terjadi setelah hari raya Idul Fitri, Idul Adha, atau terjadi serangan penyakit. Tingginya permintaan ternak pada hari raya Idul Fitri dan Idul Adha menyebabkan perusahaan mengalami stockout setelah hari raya. Ternak yang dipasarkan PT X pernah terserang penyakit yang terjadi di salah satu SPR naungan PT X. Penyakit tersebut banyak menyerang ternak domba sehingga ternak domba mengalami stockout karena harus dikarantina terlebih dahulu dan tidak dapat dipasarkan.

Sistem Pengiriman. PT X sebagai perusahan marketplace ternakonline membutuhkan sistem pengiriman yang tepatdalam mendistribusikan produknya ke tangan konsumen. Sistem pengiriman menjadi faktor penting bagi PT X dalam menjaga kualitas ternak sebelum sampai ke konsumen. Sistem pengiriman yang tepat akan mencegah kematian dan luka pada ternak selama pengiriman sehingga ternak yang diterima sesuai dengan informasi yang dideskripsikan pada aplikasi beternak online PT X.

Pengiriman ternak oleh PT X dilakukan melalui kerjasama dengan transportasi lokal. Transportasi lokal yang digunakan dalam pengiriman disesuaikan dengan jumlah ternak yang dikirim yaitu trukdan mobil pick up. Jumlah ternak yang dikirimkan PT $\mathrm{X}$ disesuaikan dengan kapasitas kendaraan. Frekuensi pengiriman PT X dilakukan sesuai dengan permintaan yang ada. PT X dalam pengirimannya dilakukan pengelompokkan berdasarkan lokasi pengiriman. Hal ini bertujuan untuk menghemat biaya pengiriman. Hal ini bertujuan untuk menghemat biaya pengiriman. Pengelompokkan tersebut didasarkan jumlah permintaan ternak yang ada bervariasi. Permintaan ternak dengan jumlah satuan harus dikelompokkan dangan permintaan pembeli yang lain agar jumlah yang dikirim memenuhi kapasitas kendaraan dan biaya pengiriman tidak terlalu tinggi.

\section{Aktor}

Pengambilan keputusan strategi pemasaran online ternak PT X melibatkan 3 aktor yang memiliki peran penting dalam penentuan strategi pemasaran ternak online. Aktor tersebut meliputiFounder, Kordinator Mobile Sentra, dan Support Service yang memiliki kesamaan tujuan. Founder bertugas sebagai pemimpin perusahaan yang bertanggungjawab atas semua kegiatan perusahaan secara keseluruhan dan memiliki kuasa penuh atas penyusunan strategi perusahaan termasuk strategi pemasaran. Koordinator Mobile Sentra bertugas dalam perluasan kandang, ekspansi ke daerah, dan pengawasan terhadap SPR. Support Service bertugas dalam mengelola media sosial yang berhubungan langsung dengan konsumen, sebagai custommer service perusahaan yang menerima keluhan dan saran dari konsumen.

\section{Alternatif}

Menjaga Kualitas Produk. PT X sebagai perusahaan ternak online bergantung terhadap kualitas ternak yang dipasarkan. Ternak tersebut harus memiliki kualitas yang sesuai dengan informasi yang tertera secara online. Kualitas produk ini dipengaruhi oleh jenis ternak yang dipasarkan, harga produk, tempat pemeliharaan produk, ketersediaan ternak, dan sistem pengiriman ternak ke tangan konsumen. Kualitas produk menjadi tolak ukur konsumen dalam melakukan pembelian lebih lanjut.

Kualitas menurut Gaspersz (2001) memiliki 2 definisi yaitu definisi konvensional dan definisi strategik. Kualitas yang menggambarkan karakteristik langsung dari suatu produk seperti performansi, keandalan, mudah digunakan, dan estetika adalah definsi konvensional. Definisi strategik kualitas adalah segala sesuatu yang mampu memenuhi keinginan atau kebutuhan pelanggan dan keunggulan produk dapat diukur dari kepuasan pelanggan. Kualitas produk hewan ternak PT X secara konvensional dapat dilihat melalui performa tubuh dan bobot badan yang tersedia pada aplikasi milik PT X. Kualitas secara strategik pada ternak PT $\mathrm{X}$ dapat dilihat melalui sistem pembelian yang dilakukan secara online. Hal ini sesuai dengan harga ketersediaan produk.

Memperluas Hubungan Kerjasama. Hubungan kerjasama umumnya dilakukan oleh pihak-pihak yang memiliki tujuan terkait satu sama lain. PT X sebagai perusahaan marketplace ternak online memiliki hubungan terkait dengan beberapa pihakdalam mengembangkan perusahaannya. PT X saat ini telah melakukan hubungan kerjasama dengan pihak perbankan, layanan provider, jasa asuransi dan mitra. PT X dalam memajukan perusahaannya haruslah melakukan perluasan hubungan kerjasama yang merupakan kombinasi dari bauran place (lokasi), promotion (promosi), dan process (proses).

Perluasan hubungan kerjasama PT X dilakukan dengan menjalin kerjasama dengan pihak jasa ekspedisi, akademisi, dan SPR. Jasa ekspedisi dapat membantu dalam proses pengiriman ternak kepada konsumen bahwa saat ini PT X masih melakukan pengiriman ternak menggunakan transportasi lokal. Jas. Akademisi dapat membantu PT X sebagai konsultan untuk memberikan saran dalam menjaga dan meningkatkan kualitas produknya. PT X sebagai perusahaan marketplace beternak online memperluas hubungan kerjasama dengan SPR sebagai tempat pemeliharaan dan penyedia ternak.

Meningkatkan Sistem Pelayanan. Alternatif meningkatkan sistem pelayanan merupakan hasil kombinasi dari bauran people (orang), physical environment (bukti fisik), dan process (proses). Sistem pelayanan merupakan prosedur atau tata cara untuk memberikan pelayanan kepada pelanggan dengan melibatkan seluruh fasilitas fisik yang dimiliki dan SDM yang ada. Kasmir (2008) menyatakan untuk meningkatkan citra perusahaan wirausahawan perlu menyiapkan sumber daya manusia (karyawan) yang mampu memenuhi keinginan dan kebutuhan pelanggannya. Hal ini sesuai dengan bauran people (orang) yaitu semua pelaku yaitu pengelola memiliki peran penting dalam penyajian jasa sehingga dapat mempengaruhi persepsi pembeli.

Karyawan yang diharapkan dapat melayani keinginan dan kebutuhan pelanggan. PT X sebagai perusahaan marketplace dalam pemasaran ternak online menawarkan pelayanan jasa dalam memenuhi kebutuhan konsumen akan hewan ternak. Sistem pelayanan ini menjadi salah 
satu alternatif penting yang diperhatikan oleh PT X dalam mengembangkan perusahaannya. PT X memiliki suatu proses dalam sistem pelayanannya dengan melibatkan SDM dan fasilitas yang ada. Sistem pelayanan yang tepat dapat meningkatkan permintaaan pasar untuk beternak online.

PT X dalam mengembangkan sistem pelayanannya telah memiliki sistem layanan keluhan konsumen dan berencana meningkatkan keamanan dalam proses pembayaran online. Layanan keluhan konsumen terdapat pada website resmi PT X yang membantu konsumen untuk menyampaikan keluhan dan pertanyaan terkait aplikasi beternak online PT X. PT X juga berencana meningkatkan keamanan sistem pembayaran online untuk memberi kenyamanan saat pembayaran. Peningkatan keamanan sistem pembayaran dilakukan melalui kerjasama dengan perbankan yaitu pembeli mendapatkan tanda bukti pembayaran secara resmi.

\section{Analisis Pemilihan Alternatif Strategi Pemasaran} Ternak Online PT X dengan Metode AHP

Unsur yang telah diidentifikasi kemudian disusun menjadi struktur hirarki (Gambar 2). Struktur hirarki ini diolah menggunakan metode AHP (Analytical Hierarchy Process). Responden yang terlibat dalam penilaian meliputi Founder, Kordinator Mobile Sentra, Support Service, dan responden ahli yaitu seorang pakar dibidang komunikasi bisnis.

\section{Pengolahan Faktor}

Hasil analisa AHP (Analytical Hierarchy Process) mengenai preferensi terhadap faktor (Gambar 2), didapatkan bahwa secara umum PT X lebih memprioritaskan faktor ketersediaan produk $(0,875)$ yang mempengaruhi penyusunan kebijakan strategi pemasaran ternak online PT X. Jumlah ketersedian produk yang dapat memenuhi permintaan konsumen menjadi modal dalam penyusunan strategi pemasaran. Faktor ketersediaan produk juga mempengaruhi wilayah pemasaran dan target pasar yang dituju perusahaan. Produk yang disediakan PT X meliputi ternak domba dan sapi. Jumlah produk yang tersedia selalu dikontrol setiap bulannya untuk memperbarui informasi yang tercantum pada aplikasi. Jumlah hewan ternak yang tersedia bersifat fluktuatif yang disesuaikan dengan keadaan SPR. SPR yang sesuai dengan kriteria PT X berjumlah terbatas sehingga menyebabkan ternak yang tersedia untuk dipasarkan bersifat terbatas.

PT X dalam menjaga jumlah ketersediaan ternaknya melakukan pengontrolan terhadap SPR terkait setiap bulannya dan melakukan ekspansi ke daerah. Sistem pengiriman merupakan faktor selanjutnya yang mempengaruhi perumusan strategi pemasaran ternak online PT X (bobot 0,125). Sistem pengiriman berperan dalam mendistribusikan produk yang dibeli oleh konsumen. Sistem pengiriman dalam proses pemasaran ternak menjadi faktor yang dapat mempengaruhi keadaan ternak. Sistem pengiriman yang tepat akan menghindari ternak mengalami luka, kematian, dan penurunan bobot badan yang drastis saat dikirim ke konsumen.

PT X dalam mengirimkan hewan ternak kepada konsumen menggunakan transportasi darat berupa mobil truk yang disesuaikan dengan kapasitas hewan ternak dan jarak perjalanan. Trukyang digunakan merupakan kerjasama PT X dengan transportasi lokal. Ilham dan Yusdja (2004) menyatakan bahwa sarana transportasi ternak menggunakan transportasi darat yaitu truk dan kereta api serta transportasi laut. Transportasi yang digunakan dalam pengiriman merupakan kerjasama dengan transportasi lokal di daerah sekitar.

\section{Pengolahan Aktor}

Aktor yang berperan dalam pengambilan keputusan strategi pemasaran adalah Founder, Koordinator Mobile Sentra, dan Support Service. Ketiga aktor saling terkait

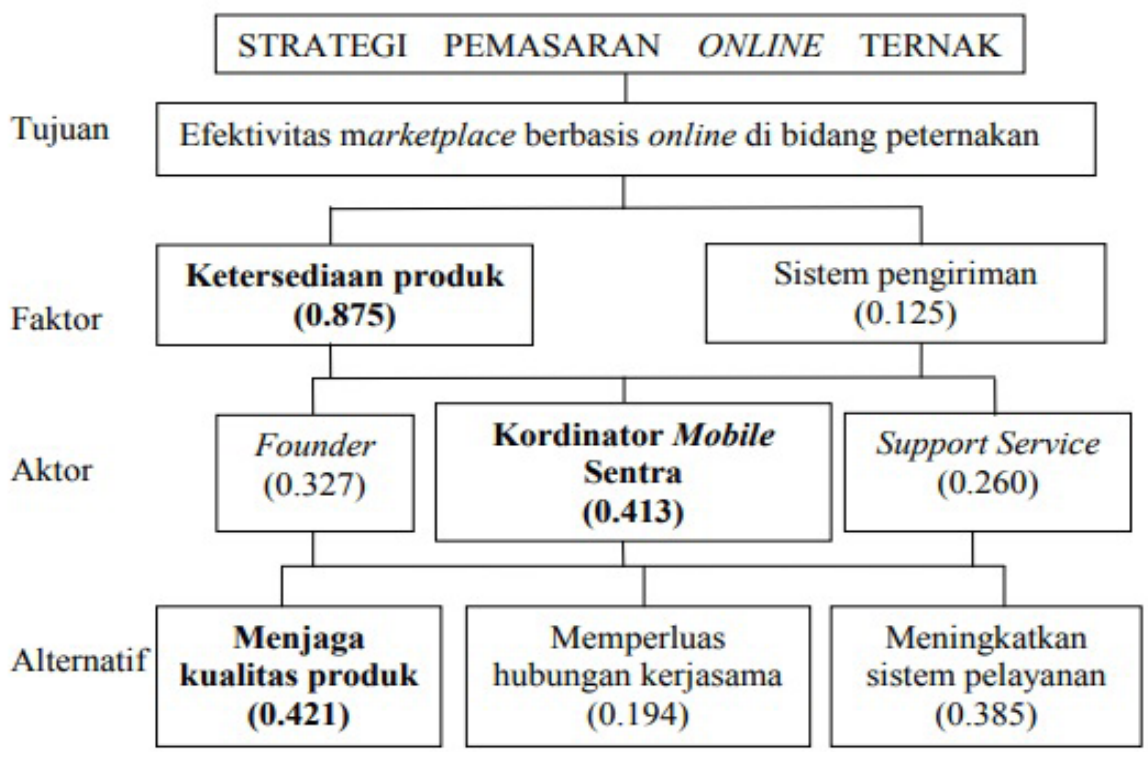

Gambar 2. Hasil pengolahan hirarki strategi pemasaran online ternak 
dengan faktor-faktor penyusun bauran pemasaran. Hal ini dikarenakan bisnis melalui media internet memerlukan pendapat dari orang yang terlibat langsung dalam pengelolaan dan pengembangannya (Kurnia 2008). Konteks ketersediaan produk memiliki nilai inkonsistensi di bawah 10\% dansangat dipengaruhi oleh KoordinatorMobile Sentra dengan bobot 0,413 dibandingkan Founder $(0,327)$ dan Support Service (0,260). Koordinator Mobile Sentra dalam konteks ini memiliki peranan lebih penting dibanding aktor lain. Hal ini dikarenakan Koordinator Mobile Sentra memiliki peranan dalam perluasan dan pengawasan SPR yang berhubungan langsung dengan ketersediaan produk ternak.

Founderdan Support Service memiliki peranan yang tidak berhubungan langsung dengan ketersediaan produk ternak sehingga tingkat kepentingannya lebih rendah dibandingkan Koordinator Mobile Sentra. Kontekssistem pengiriman lebih dipengaruhi oleh Support Service tetapi nilai inkonsistensinya di atas $10 \%$ sehingga diabaikan.

\section{Pengolahan Alternatif Strategi Promosi Online Perusahaan}

Alternatif yang ditawarkan untuk strategi pemasaran ternak online PT X akan berdampak baik pada perkembangan perusahaan jika dijalankan dengan baik. Strategiutama yang dapat diterapkan adalah dengan menjaga kualitas produk $(0,421)$. Produk menurut Kotler (2001) adalah segala sesuatu yang ditawarkan ke pasar untuk memuaskan kebutuhan dan keinginan. Produk yang ditawarkan oleh suatu perusahaan haruslah memiliki kualitas yang dapat memenuhi permintaan pasar. Kualitas produk ini mempengaruhi minat pasar dalam menerima produk yang ditawarkan.

Ternak merupakan produk hidup yang mungkin mengalami luka, penyakit, dan kecacatan sehingga kualitasnya riskan mengalami penurunan. PT X dalam menjaga kualitas hewan ternak yang dipasarakan senantiasa mengoptimalkan standarisasi SPR dan monitoring peternak secara berkala. Standarisasi SPR dilakukan agar ternak yang dipelihara di SPR terkait tidak mengalami penurunan kualitas. PT X terus berupaya mencari mitra peternak dengan kualifikasi yang seusuai untuk menjaga kualitas produk kedepannya.

Meningkatkan sistem pelayanan berada di prioritas kedua dengan bobot 0,385 . Kemudahan sistem pemasaran online yang cepat dan memiliki sasaran pasar yang luas menuntut tingkat profesionalisme yang tinggi. Semakin berkembang dan maju suatu perusahaan maka semakin meningkat sistem pelayanan yang diberikan. Sistem pelayanan yang disediakan PT X untuk konsumen saat ini adalah disediakannya layanan keluhan konsumen dan sistem pembayaran online yang aman. Layanan konsumen membantu konsumen dalam menyampaikan keluhannya secara langsung kepada perusahaan. PT X kedepannya berencana meningkatkan keamanan dalam sistem pembayaran online sehingga konsumen tidak merasa khawatir tentang pembayaran online.

Alternatif lainnya adalah dengan memperluas hubungan kerjasama $(0,194)$. Perluasaan hubungan kerjasama dilakukan dalam mengembangkan dan memperluas pemasaran produk perusahaan. PT X saat ini telah menjalin kerjasama dengan beberapa pihak seperti perusahaan layanan provider, penyedia jasa asuransi, perbankan, dan mitra. Kerjasama yang dilakukan PT X disesuaikan dengan kebutuhan perusahaan. PT X di waktu mendatang berencana memperluas hubungan kerjasama dengan pihak peternak di luar negeri dan akademisi. Hubungan kerjasama dengan peternak di luar negeri diharapkan dapat memperluas pemasaran dan memenuhi ketersediaan produk hewan ternak yang sesuai dengan kualifikasi perusahaan. Kerjasama dengan akademisi akan dilakukan PT X untuk membantu dalam mengevaluasi sistem yang digunakan sehingga perusahaan dapat lebih baik.

\section{KESIMPULAN}

Ketersediaan produk menjadi faktor prioritas dalam penyusunan strategi pemasaran PT X. Koordinator Mobile Sentra memiliki peranan terpenting sebagai aktor. Menjaga kualitas produk menjadi strategi utama yang dapat diterapkan PT X dalam meningkatkan pemasarannya.

\section{DAFTAR PUSTAKA}

Assauri, S. 2015. Manajemen Pemasaran: Dasar, Konsep, dan Strategi. Raja Grafindo Persada, Jakarta.

Cant, M., J. Strydom, C. Jooste, \& Pd. Plessis. 2006. Marketing Managemen. Ed ke-5. Juta \& Company, South Africa.

Lamb, C. W., J. F. Hair, \& Mc Daniel. 2001. Pemasaran. Ed ke-1. Jakarta(ID): Salemba Empat.

Chen, Y. Y., H. L. Huang, Y. C. Hsu, H. C. Tseng, \& Y. C. Lee. 2010. Confirmation of expectations and satisfaction with the internet shopping: the role of internet self-efficacy. CIS. 3(3) : 14-22.

Echdar, S. 2013. Manajemen Entrepreneurship: Kiat Sukses Menjadi Wirausaha. Andi Publisher, Yogyakarta.

Tjiptono, F. 2002. Perspektif Manajemen dan Pemasaran Kontemporer. Andi Publisher, Yogyakarta.

Gaspersz , V. 2001. ISO 9001:2000 and Continual Quality Improvement. Gramedia Pustaka Utama, Jakarta.

Ilham, N., Y. Yusdja. 2004. Sistem Transportasi Perdagangan Ternak Sapi dan Implikasi Kebijakan di Indonesia. Bogor (ID): Pusat Penelitian dan Pengembangan Sosial Ekonomi Pertanian.

Kasmir. 2008. Bank dan Lembaga Keuangan Lainnya Ed Revisi. Rajagrafindo Persada, Jakarta.

Kotler, P. 2001. Manajemen Pemasaran: Analisis, Perencanaan, Implementasi dan Kontrol. Prehallindo, Jakarta.

Rahardjo, S., Gudnanto. 2011. Pemahaman Individu Teknik Non Tes. Nora Media Enterprise, Kudus.

Saaty, T. L. 2001. The Analytic Network Process: Decision Making with Dependence and Feedback. RWS Publications, Pittsburg.

Shaw, M., R. Blanning, T. Strader, \& A. Whinston. 2012. Handbook on Electronic Commerce. Springer Science and Bussiness Media, New York. 
Wiradarya, T. R. 2004. Peningkatan produktivitas ternak domba melalui perbaikan nutrisi rumput lapang. Laporan Penelitian. Bogor, Institut Pertanian Bogor.

Zeithaml, V. A., M. J. Bitner, D. D. Gremler. 2013. Service Marketing. Ed ke-6. Mc Graw Hill, America. 